17 McDonald WI, Halliday AM.Diagnosis and classification of multiple sclerosis. Br Med Bull 1977;33:4-8.

18 Swingler RJ, Compston DAS. The prevalence of multiple sclerosis in South East Wales. J Neurol Neurosurg Psychiatry 1988;51:1520-4.

19 Report of the joint working party on medical staffing structure in the hospital service. 1977. London: Her Majesty's Stationery Office.

20 Medical and dental staffing prospects in the NHS in England and Wales. DHSS. Health Trends 1986;18:49-56.

21 Sander JWA, Shorvon SD. Incidence and prevalence studies in epilepsy and their methodological problems: a review. J Neurol,
Neurosurg, Psychiatry 1987;50:829-39.

22 Wilkin D, Smith AG. Variation in general practitioners' referra rates to consultants. $J R$ Coll Gen Pract 1987;37:360-3.

23 Morrow JI, Patterson VH. The neurological practice of a district general hospital. J Neurol Neurosurg Psychiatry 1987;50: 1397-1401.

24 Kurtzke JF, Bennett DR, Beringer GB, Goldsten M, Vates TS. Neurologists in the United States-past, present and future. Neurology 1986;36:1576-82.

25 Dyken ML. The continuing undersupply of neurologists in the 1980s: impressions based on data from three studies. Neurology 1982;32:651-6.

\title{
Scrotal reflex
}

"If, in children whose scrotum is relaxed, we press the finger upon the inner surface of the thigh, the testicle of the same side is drawn up, in consequence of a reflex action."

Romberg, MH. A Manual of the Nervous Diseases of Man, edited and translated by H Sieveking. London: The Sydenham Society, 1853.

RT ROSS

\section{Aphasia}

"It is quite necessary to distinguish two different phenomena in the act of speech, namely, the power of creating words as signs of our ideas and that of articulating these same words. There is, so to speak, an internal speech and an external speech; the latter is only the expression of the former."

Bouillaud, JB. Recherches cliniques propres a demontrer que la perte de la parole correspond a la lesion des lobules anterieurs de cerveau. Arch Gen Med 1825;8:25.

\section{Poliomyelitis}

"In the year 709 the ANNALS OF ULSTER record: "Pestis Quae Dicitur and Baccach, Cum Uentris Profluuiis, in Hibernia". MacArthur' discusses the possible identification of Baccach, which he translates as "lameness" in the sense of "weakness or disablement of any limb upper as well as lower". He says "the problem is to name an epidemic disease which might have given rise to numerous cases of paralysis or weakness of limbs ... I venture to suggest that the Baccach of 709 may have been poliomyelitis, popularly called "infantile paralysis", although it is far from being restricted to children. ... The initial phase of the infection would have passed the understanding of any monk of old, but no one could have failed to observe the trail of cripples left behind."

\section{References}

1 MacArthur, Sir William Porter. The identification of some pestilences recorded in the Irish Annals. Irish Historical Studies 1949;VI,169-88.

2 Bonser, William. The Medical Background of Anglo-Saxon England. London: The Welcome Historical Medical Library, 1963,83 .

RT ROSS

\section{The myopathies or muscular dystrophies}

"It has been shown that the distal type is a true myopathy and distinct from the disease described by Charcot, Marie, and Tooth (peroneal type), which is a myelopathic affection and should not be included under the myopathies."

Batten, Frederick E. $Q J$ Med 1909-10;3:313-27. 